Article

\title{
Perceived Value in Sporting Events (PVSP): A Further Step for the Strategic Management
}

\author{
Josep Crespo Hervás ${ }^{1}$, Vicente Prado-Gascó ${ }^{2}$ [D and María Huertas González-Serrano ${ }^{1,3, *}$ \\ 1 Department of Physical Education and Sports, Faculty of Physical Activity and Sport Sciences, \\ Universitat de València, 46010 Valencia, Spain; josep.crespo@uv.es \\ 2 Department of Social Psychology, Faculty of Psychology, Universitat de València, 46010 Valencia, Spain; \\ vicente.prado@uv.es \\ 3 Department of Teaching and Learning of Physical Education, Plastic and Music Education, \\ Universidad Católica de Valencia, 46110 Valencia, Spain \\ * Correspondence: mh.gonzalez@ucv.es
}

Received: 18 June 2020; Accepted: 3 July 2020; Published: 8 July 2020

check for updates

\begin{abstract}
The perception of sporting events spectators is a crucial area of research in the sport management field. These studies analyze different variables, the perceived value of which has gained relevance in recent years. By providing superior value to consumers, organizations can achieve a competitive advantage and guarantee their sustainability. However, a limitation found in the literature is that most of the scales used to measure it are one-dimensional or with single items, and do not provide enough information. Therefore, this study aims to analyze the psychometric properties of the Multidimensional Scale of Perceived Value (PVSE) for the evaluation of sporting events. The questionnaire was administered to a sample of 497 spectators with an average age of 36.57 years $(\mathrm{SD}=12.23)$ at a basketball sporting event. The results showed the validity of the multidimensional structure of this scale for sporting events $\left(\chi^{2}(\mathrm{gl})=981.22(284)\right.$; $\mathrm{S}-\mathrm{B} \chi^{2}(\mathrm{gl})=0.93$; $\mathrm{NNFI}=0.94 ; \mathrm{IFC}=0.94 ;$ Incremental F Index $(\mathrm{IFI})=0.94 ;$ RMSEA $(\mathrm{IC})=0.057(0.05-0.06))$. Specifically, six dimensions were found to be the appropriate psychometric properties of the scale $(\alpha=0.81)$. This multidimensional scale of perceived value can be a useful tool for the evaluation of sports consumer experiences, considering both the benefits and sacrifices that a spectator makes when attending a sporting event. Hence, sport managers will be able to discover how to create policies to provide more value to sports spectators, which will be reflected in the sustainability of sporting events.
\end{abstract}

Keywords: perceived value; sporting events; marketing; strategic planning; sustainability

\section{Introduction}

In recent years, in parallel with the growing importance of sporting events as elements of city promotion [1-3], and with the positive perception of sports in society as a promoter of quality of life and positive values [4-6], different studies have tried to assess the management and outcomes of these events. However, the great variety and types of events, as well as the objectives of researchers and managers, make it challenging to find tools that are generally suitable for all [7]. This difficulty is due to the fact that the number of sporting events held both nationally and internationally has increased in recent years [8], as has its heterogeneity at the same time. Hence, this reality makes it difficult to compare some studies with others and opens up avenues for discussion to find points of agreement to make progress in improving the management of sporting events.

The success of a sporting event is a vital result both for the organizing entity and for the city where the event has been held [8]. Therefore, it is essential to identify how the sporting event benefits the community [9]. Within these points of agreement, it is common to evaluate sporting events by analyzing 
the perception of participants $[8,10]$ and spectators $[11,12]$, as well as the residents' perceptions of the community where these events are hosted [13-15]. These evaluations can provide useful information to ensure the success of a sporting event and can help event organizers implement different marketing strategies that could improve their perceptions.

Concerning the variables used as outcomes of the management success of the sports services, satisfaction and future intentions are the most commonly used [16-20]. Among the variables studied to provide these outcomes, we can find service quality [21-24] and perceived value [25-27], together with others, such as emotions [16,28], identity with teams [29,30], or attendance reasons [31,32]. The quality of service is, by far, the most studied and discussed in the literature [33]. However, among the discussions of its results, some shortcomings are evident in terms of collecting all the information on the perceptions of the spectators [34].

For these reasons, perceived value has attracted the attention of researchers during the last years. Perceived value has been considered a key variable, since it is closely related to satisfaction and future intentions [27,35], and predicts future intentions better than satisfaction does $[16,36,37]$. Both academic researchers and marketing practitioners have recognized the major influence that perceived value has on consumer behavior [38], considering it the heart of the marketing approach [39]. Hence, managers should focus on the service value they offer because satisfaction alone is not a valid predictor of intentions [16].

In this sense, the perceived value understood as a multidimensional variable collects specific information similarly to the perceived quality and allows the incorporation of negative dimensions, which make it possible to consider more elements of judgment to understand the behavior of clients [40]. However, a limitation found in this field of study is that most scales used to measure perceived value are one-dimensional [41-43], and thus do not reflect the nature of the sport consumption experience [44] adequately. For instance, the perceived value scaled created by [41] is composed of five items that focus only on the relationship of the cost that customers paid for the service they receive in a baseball game. In the same vein, in [42], the authors also used a unidimensional scale to measure perceived value in sport spectators, focusing on the relationship between price and quality. In addition, other authors [43] have used different scales composed of two items to measure perceived value. One of these items was related to the overall value of the facility's service, and the other one related to the relationship of the sacrifices that a person makes to receive the service and their satisfaction with it. However, as can be observed, all of these scales are based on the price/service ratio offered, and do not provide useful information on which specific aspects of the perceived value could be improved. Hence, in recent years, the importance of developing multidimensional scales to measure this variable has been recognized in the literature [40,44-46].

However, even in the field of sports in general, and especially in sporting events, the multidimensional scales to measure this variable are scarce. Research to date has preferred to use a unidimensional conceptualization of perceived value. This fact provides an opportunity for further work, which captures the broader domains that contribute to consumers' perceived value within the sport context [44]. In order to address this identified gap, this study aims to adapt a multidimensional scale of perceived value to the context of sporting events to analyze its psychometric properties, and to analyze how these different dimensions affect the satisfaction and future intentions of sports spectators. This study goes a step further than previous multidimensional scales developed to measure perceived value [44] in general, and specifically in the sports sector [45], by incorporating both benefit (positive) and cost (negative) dimensions. This scale is capable of determining specific elements of the service that make it possible to obtain information for managers to improve the events and guarantee the sporting events' sustainability. The few studies of multidimensional value found, specifically concerning sporting events, create the need to study the behavior of these tools, and to compare them with studies from other fields in service marketing and sports services, as well as with different types of value constructs, such as one-dimensional value and other variables. Hence, it is the first scale to measure perceived quality in sporting events that incorporate both positive and negative dimensions. 


\subsection{Literature Review}

The growing body of research into the concept of perceived value highlights that organizations can achieve a competitive advantage by providing superior value to consumers [47]. Hence, perceived value has received much attention in the marketing literature as an outcome variable in explaining consumption behavior as either a direct or mediating predictor variable $[22,48,49]$. The consumers' perceived value is closely related to the quality or the benefits they perceive from the product or service in exchange for the price they pay [50]. Customer value is also defined as "the customer's overall assessment of the utility of a product on perceptions of what is received and what is given" [50] (p. 14). Hence, customer value is defined by the relationship between the benefits they receive in comparison to the sacrifice of their intangible resources [27]. This way of understanding value is the most common and accepted, since it can include all the other definitions. Hence, it seems to be a consensus that value is perceived by consumers or customers $[50,51]$, and that value includes benefits and sacrifices.

Other authors understand the perceived value, considering the perceived utility of the product or service. In this vein, Reference [52] defines value as the perceived preference and evaluation of the attributes of a product, the attributes of the result, and the consequences of use that facilitate or block the achievement of the objectives and purposes of consumer use. Other definitions of value are based on the relationship between quality and price, while quality is understood as the fulfillment of expectations. The concept of value goes beyond this and includes costs and not only benefits. Other authors understand perceived value as the quality perceived by the market corrected by the price of the product [53].

Therefore, in recent years, interest in the multidimensional approach has been aroused, and several authors have introduced it in their definitions. For example, the authors of [54] define value as a multidimensional construct that considers perceived value as a latent factor from dimensions related to what the client receives (benefits) and what they provide in return (sacrifices). Some years later, and in the same vein, the perceived value was conceptualized as a multidimensional construct that is heterogeneous between customers [55].

However, among the initial studies that conceptualize and define the term, there is consensus on the need to use both positive and negative dimensions of value. Among these, some studies include cognitive, functional, and affective dimensions $[44,45,50,54,56]$. In studies that use affective dimensions, the main contributions are focused on the benefits to the consumer, such as social relationships or lived emotions, and also on the efforts that have to be made, such as security or perceived risk [40]. On a functional level, quality or aesthetics are mainly included as a positive dimension, and price, time, and effort as negative ones.

With all this, there are some difficulties to be considered when working with the perceived value variable. From the review of the literature, there is evidence of difficulty in comparing the definitions. The authors do not agree on the main elements of perceived value: Benefits, costs, price, quality, and sacrifices. This situation makes it difficult to compare the concepts of perceived value from some research and others [57]. There are also definitions based on a single direction—only benefits—or bidirectional, considering the relationship between benefit and sacrifice. On the other hand, opinions are divided as to the affective and cognitive components of perceived value. Thus, some authors consider perceived value as a cognitive variable [50,58,59], while others maintain that the affective component should be included. In addition, there is no consensus on which dimensions comprise perceived value [54,60-62], as well as on the elements that make up each of the positive and negative dimensions of value [52]. Hence, the perceived value is measured both by assessing the variety of a consumer's experience [54] and by measuring the discrepancy between the actual cost and perceived benefit $[38,63,64]$.

A multidimensional approach to perceived value can provide a more significant variability to explain the various ways in which customers evaluate services and products. However, the unidimensional approach to measuring the perceived value that captures costs is the most common approach adopted in sports marketing research $[48,49]$. Nevertheless, while this approach 
may be appropriate for fast-moving consumer goods, the definition of value from a cost evaluation perspective does not adequately reflect the nature of the sports consumption experience [44]. Hence, it is necessary to use a multidimensional scale to measure perceived value in sports customers.

In this vein, the theory of consumption values [65] provides a multidimensional conceptualization of consumers' perceived value. The theory proposes that a consumer's overall perceived value is derived from five dimensions: (1) Functional value, (2) emotional value, (3) social value, (4) conditional value, and (5) epistemic value. Some years later, in the sports service context, Reference [46] proposed three types of values: Practical value (functional objects of the service encounter), emotional value (feelings expressed during the service experience), and logical value (the rational elements of the service experienced or delivered: Correct price, correct information ... ). Three years later, reference [49] classified this set of constructs into utilitarian and symbolic aspects. Finally, the most recent study, Reference [44], developed a multidimensional Consumers' Perceived Value of Sport with five dimensions: Functional, economic, social, epistemic, and emotional.

However, among all of the value typologies, the approach of [66] stands out as the most commonly used classification. He distinguishes between three important realities of consumption that come together: (1) The affective dimension manifested in intrinsic values, such as entertainment; (2) the more utilitarian dimension, i.e., that which allows products to be valued for their functionality (their efficiency and their quality); and (3) the social dimension, which can range from esteem or status to ethical value. In this study, the perceived value variable is understood as a multidimensional variable, which includes both the benefits and the sacrifices that the client perceives in experiencing the service, which must consider as many relevant aspects in the clients' decisions, quality, price, and functional, emotional, and cognitive aspects. Hence, Reference [66] was used to identify the positive dimension of the perceived value (social value, efficiency, and entertainment), like previous studies $[40,67]$. In addition, three negative or sacrificial dimensions represent the cost values most commonly considered in the literature: Monetary cost, perceived risk, and time and effort invested [40]. Hence, the following six dimensions are proposed for the development of the multidimensional scale of perceived value for sporting events:

1. Social value (SOV): Social value can be defined as the utility derived from the ability of sports team game consumption to enhance social self-capital [54]. Attendance at sporting events provides consumers with opportunities to build social bonds and improve the acceptance of peer groups $[31,68]$. In the sporting events context, this value is measured by the perception that spectators have of their acceptance in other groups (status), as well as the interaction they make with other people during the event.

2. Efficiency value (EFV): Efficiency can be understood as a ratio of outputs to inputs, that is, a comparison of what is obtained in an exchange relationship with what is given for the purchase (money, time, effort ... ) [65]. In the same vein, Reference [69] defined the efficiency component as "consumer return on investment, including the active investment of financial, temporal, behavioral, and psychological resources that potentially yield a return". This value in the context of sporting events is measured as the perception that the spectators have about the intangible aspects and the services that are offered near the place of celebration of the event.

3. Entertainment value (ENV): Entertainment corresponds to the aspect of active hedonism, that is, to get involved in enjoyment and fun [67]. In the same vein, Reference [70] highlights entertainment as an active value that is part of the hedonistic dimension. Hence, on this scale, this value is measured as the degree of enjoyment perceived by the spectators during the sporting event.

4. Price and Monetary Cost Value (PMCV): The price influences the price and monetary cost value concerning the perceived quality of the product or service by the consumer [50]. Some authors found that perceived economic value is positively influenced by consumers' intentions to attend sports games [41]. In this case, this variable in the context of the sporting events is measured as the perception they have of the money spent on the sporting event (ticket, accommodation ... ). 
5. Perceived Risk Value (PRV): Perceived risk has a variety of conceptualizations [71,72]. The concept of perceived risk most often used by consumer researchers defines risk in terms of the consumer's perceptions of the uncertainty and adverse consequences of buying a product (or service) [73]. This variable in the sporting events context is measured as the risk perceived by consumers when attending that specific event.

6. Time and effort value (TEV): Time and convenience are increasing their importance to consumers [74], and many authors have recognized that time should be viewed as an essential input in an assessment of value [50,66,75]. Other authors [76] highlighted that: "Time is perceived as having value and as capable of being bought and spent as well as being saved and wasted" (p. 29). In the context of sporting events, this value is measured as the perception of time that consumers think they have sacrificed or lost by attending the event.

Hence, this structure is proposed for the validation of a multidimensional value scale of six elements, of which three are benefits (SOV, EFV, and ENV) and three are costs (PMCV, PRV, and TEV).

Perceived Value, Satisfaction, and Future Intentions

Concerning the relationship between customer value and satisfaction, the linkage between these two variables has been well examined in the literature of service marketing $[43,77,78]$. Perceived value can easily be confused with satisfaction [54], although there is a clear difference: While perceived value occurs at various phases of the acquisition or purchase process, including pre-purchase [52], satisfaction is a post-use or post-purchase evaluation [79]. Satisfaction is defined as "both an evaluative and emotion-based response to a service encounter" [43] (p. 204). The perceived value is connected to client satisfaction [80].

Some empirical studies have studied the relationship between perceived value and satisfaction, suggesting that satisfaction is positively influenced by perceived value $[37,40,43,63,81]$. Regarding the consequences of value, there is a consensus that satisfaction has a direct and positive relationship with perceived value $[18,40,43,82-85]$. Hence, it is possible to find satisfaction as an antecedent, as well as a consequence of perceived value. However, researchers have offered more support for perceived value positively and directly impacting client satisfaction (Cronin et al., 2000). Moreover, in the context of sport service, it also has been confirmed that perceived value is a critical predictor of customer satisfaction $[25,64,86-89]$.

On the other hand, some studies found this positive relationship between value and future behavioral intentions $[26,90,91]$. Several studies suggest that perceived value is one of the most critical determinants of repurchase intention and return or revisiting intention [92-94]. However, while the relationship between value and loyalty has been shown to be significant [25], others argue that part of the influence of service value on repurchase intention is through satisfaction [22,95]. This means that satisfaction is a partial mediator in the relationship between value and repurchase intention [96]. In addition, other researchers suggest that perceived service value influences loyalty only through satisfaction, and that the direct relationship between service value and repurchase intent is not significant [37].

Moreover, some previous research highlighted that perceived value is also a better predictor of future intentions than is satisfaction $[16,36,64]$. Due to the fact that both satisfaction and future intentions are important outcomes of attitudes and behaviors that can be influenced by the perceived value of sporting events consumers, the following two hypotheses were developed:

Hypothesis 1: Spectators' perceived value of the sporting event has a direct and positive association with their satisfaction.

Hypothesis 2: Spectators' perceived value of the sporting event has a direct and positive association with their future intentions. 


\section{Materials and Methods}

\subsection{Participants}

The sample is made up of a total of 497 spectators who attended the games of a first division club basketball team for one year. All questionnaires that were completed by persons under 18 years of age or who completed less than $80 \%$ of the questionnaire were eliminated. Of the 497 participants in the study, the range was between 18 and 76 years of age $(\mathrm{M}=36.57$; $\mathrm{SD}=12.23)$. Of these, $68.10 \%$ were men, while $31.90 \%$ were women. Regarding the residence of the population, the majority appeared to reside in the capital city of Valencia $(40.10 \%)$ or, failing that, in the metropolitan area $(36.30 \%)$. On the other hand, if the academic level is considered, most of the participants in the study had completed university studies $(44.20 \%)$ or secondary studies $(38.90 \%)$. Finally, regarding the attendance to the matches, $74.70 \%$ claimed to attend practically all the matches.

\subsection{Instrument}

A questionnaire composed of different scales was used for data collection. All scales use a Likert answer alternative with seven points, with one meaning "Strongly Disagree" and seven meaning "Strongly Agree". These scales are described in detail below:

- Multidimensional Perceived Value Scale: Multidimensional scale composed of 26 items and six dimensions that have been adapted to sporting events based on the scale created by [40] for tourist events. The questionnaire had shown adequate psychometric properties in previous studies [67].

- General satisfaction scale: A one-dimensional scale adapted from [97], in which five items were used. This questionnaire had shown adequate psychometric properties in previous studies [98,99], which were also confirmed in the case of this study (fit index of the Spanish version with robust correction of ML (Maximum Likelihood) and SB (Satorra-Bentler): $p<0.001 ; \chi^{2}$ (df) = 101.44 (5); $\mathrm{SB}^{2}(\mathrm{df})=30.85$ (5); NNFI (Non-Normal Fit Index) $=0.96, \mathrm{CFI}($ Comparative Fit Index) $=0.98$, IFI (Incremental Fit Index)=0.98, RMSEA (Root Mean Square Error of Approximation) =0.08; $\alpha=0.93)$.

- Unidimensional Perceived Value Scale: A one-dimensional scale composed of five items, adapted from [41], was used. The questionnaire showed adequate psychometric properties in previous studies [98,99], which were also confirmed in the case of this study (fit index of the Spanish version with robust correction of $\mathrm{ML}$ and SB: $p<0.001 ; \chi^{2}(\mathrm{df})=70.37(5)$; $\mathrm{S}-\mathrm{B} \chi^{2}(\mathrm{df})=47.26$ (5); NNFI $=0.93$, CFI $=0.97$, IFI $=0.97$, RMSEA $=0.08 ; \alpha=0.91$ ).

- Future intentions scale: A one-dimensional scale composed of four items, adapted from [100], was used to measure this variable. The questionnaire had shown adequate psychometric properties in previous studies [98,99], which were also confirmed in the case of this study (fit index of the Spanish version with robust correction of ML and SB: $p=0.03 ; \chi^{2}(\mathrm{df})=7.33(2)$; $\mathrm{S}-\mathrm{B} \chi^{2}(\mathrm{df})=5.35(2)$; $\mathrm{NNFI}=0.97, \mathrm{CFI}=0.99, \mathrm{IFI}=0.99, \mathrm{RMSEA}=0.06 ; \alpha=0.88)$.

\subsection{Procedure}

A quantitative cross-cultural design was used in this study. The data collection was done in the pavilion of a first division basketball team during all the league games. At the end of the competitions, a questionnaire was handed out to the assistants, who had to return it in the following games at the collection tables. In addition, a service was set up in the club's office. A total of 3000 surveys were handed out, of which 547 were returned. Of these, the surveys that were answered by minors, those without sociodemographic data, and those with more than $10 \%$ of the questionnaire not answered were eliminated. Finally, 493 were considered valid, and these were the participants of this study. The surveys were distributed by volunteers at random to the spectators and were distributed in equal numbers in the four matches analyzed. One of the filter questions was whether they had already answered the questionnaire, as it was not allowed for the same spectator to complete two surveys, even 
in different matches. The volunteers were looked for among the sports sciences students and the Sport Management MBA of the University of Valencia. The heads of the research group previously trained them. In total, ten volunteers per match were used, occupying each of the entrance and exit doors of the pavilion for the delivery and collection of the questionnaires. The anonymity of the data was guaranteed throughout the procedure, as well as the voluntary nature of completing the questionnaire.

\subsection{Statistical Analysis}

The statistical analysis was performed using the statistical package SPSS (Version 23, IBM Corp, Armonk, NY, USA) and EQS 6.2. First, descriptive statistics were calculated for each item, followed by an analysis of the reliability and validity of the scale. Then, the correlations between the different dimensions were calculated. Finally, the relationships between the scale of perceived value with another one-dimensional value scale, as well as with satisfaction scales and future intentions-constructs that, according to the literature, are related to perceived value through correlations and Path Analysis using Structural Equation Modeling (SEM)—will be analyzed.

\section{Results}

\subsection{Description of the Items}

The 26 items of the perceived value scale were analyzed. The final items, averages, standard deviations, total item correlations, and Cronbach's alphas without the item are shown in Table 1. Mainly, the contribution of each element to the scale seems to be satisfactory. The removal of any element does not seem to improve the reliability of the whole scale $(\alpha=0.81)$.

Table 1. Item analysis and dimension reliability: Sample size $(n)$, mean $(\bar{x})$, standard deviation (SD), item-total correlation $\left(r_{j x}\right)$, Cronbach's alpha without the item $(\alpha .-x)$, Cronbach's alpha of the dimensions $(\alpha)$, composite reliability (CR), and average variance extracted (AVE).

\begin{tabular}{|c|c|c|c|c|}
\hline Items & $\bar{x}$ & SD & $\mathbf{r}_{\mathbf{j x}}$ & $\alpha-\mathbf{x}$ \\
\hline \multicolumn{5}{|l|}{$\mathrm{EFV} \alpha=0.94 ; \mathrm{CR}=0.94 ; \mathrm{AVE}=0.80$} \\
\hline $\begin{array}{l}\text { The infrastructure around the pavilion (telephones, ATMs, electricity, street } \\
\text { cleaning, etc.) is adequate. }\end{array}$ & 3.63 & 1.60 & 0.78 & 0.94 \\
\hline $\begin{array}{l}\text { The gastronomy (meals, restaurants) in the surroundings of the pavilion is } \\
\text { adequate (qualities, waiting, spaces ... ). }\end{array}$ & 3.24 & 1.58 & 0.89 & 0.91 \\
\hline $\begin{array}{l}\text { Shops and stalls (opening hours, assortment, quality) in the area around the } \\
\text { pavilion are adequate. }\end{array}$ & 3.21 & 1.60 & 0.89 & 0.91 \\
\hline In general, I have perceived the services around the pavilion as efficient. & 3.31 & 1.64 & 0.87 & 0.92 \\
\hline \multicolumn{5}{|l|}{ SOV $\alpha=0.91 ; \mathrm{CR}=0.91 ; \mathrm{AVE}=0.64$} \\
\hline Reinforcing my status as a Pamesa Valencia fan. & 5.49 & 1.27 & 0.41 & 0.93 \\
\hline To know more about the group of spectators around me. & 4.84 & 1.39 & 0.81 & 0.88 \\
\hline To feel accepted by the group of spectators around me. & 4.80 & 1.43 & 0.76 & 0.89 \\
\hline Interacting with other viewers. & 4.86 & 1.41 & 0.85 & 0.87 \\
\hline Interacting with other people. & 4.73 & 1.43 & 0.80 & 0.88 \\
\hline Obtaining appropriate social and relationship value. & 4.83 & 1.37 & 0.83 & 0.88 \\
\hline \multicolumn{5}{|l|}{ ENV $\alpha=0.77 ; \mathrm{CR}=0.82 ; \mathrm{AVE}=0.62$} \\
\hline I have enjoyed the break periods (before, after, and halfway through the game). & 4.79 & 1.44 & 0.49 & 0.88 \\
\hline I enjoyed attending the Pamesa Valencia matches. & 5.89 & 1.02 & 0.68 & 0.63 \\
\hline Attending Pamesa Valencia matches gives me the right value of enjoyment and fun. & 5.78 & 1.05 & 0.71 & 0.59 \\
\hline
\end{tabular}


Table 1. Cont.

\begin{tabular}{|c|c|c|c|c|}
\hline Items & $\bar{x}$ & SD & $\mathbf{r}_{\mathrm{jx}}$ & $\alpha-x$ \\
\hline \multicolumn{5}{|l|}{$\mathrm{PMCV} \alpha=0.89 ; \mathrm{CR}=0.89 ; \mathrm{AVE}=0.67$} \\
\hline $\begin{array}{l}\text { I have perceived the cost associated with the disbursement of money to attend } \\
\text { Pamesa Valencia matches. }\end{array}$ & 3.58 & 1.31 & 0.74 & 0.86 \\
\hline $\begin{array}{l}\text { I have perceived the money spent on the round trip to attend the Pamesa Valencia } \\
\text { matches as... }\end{array}$ & 3.92 & 1.49 & 0.70 & 0.87 \\
\hline $\begin{array}{l}\text { I have perceived the money spent to attend the Pamesa Valencia matches and that I } \\
\text { could use for other activities as ... }\end{array}$ & 3.94 & 1.41 & 0.76 & 0.85 \\
\hline $\begin{array}{l}\text { In general, I perceived the price associated with the assistance for the Pamesa } \\
\text { Valencia parties as ... }\end{array}$ & 3.64 & 1.40 & 0.82 & 0.83 \\
\hline \multicolumn{5}{|l|}{ PRV $\alpha=0.91 ; \mathrm{CRC}=0.91 ; \mathrm{AVE}=0.77$} \\
\hline The fear of suffering an accident like ... & 5.54 & 1.60 & 0.76 & 0.90 \\
\hline Fear of being a victim of an act of delinquency such as ... & 5.40 & 1.60 & 0.79 & 0.88 \\
\hline $\begin{array}{l}\text { In general, I have perceived the risks associated with attending Pamesa } \\
\text { parties as ... }\end{array}$ & 5.48 & 1.55 & 0.88 & 0.81 \\
\hline \multicolumn{5}{|l|}{ TEV $\alpha=0.90 ; \mathrm{CR}=0.90 ; \mathrm{AVE}=0.61$} \\
\hline $\begin{array}{l}\text { I have perceived the cost of time spent in preparing for Pamesa Valencia } \\
\text { matches as ... }\end{array}$ & 4.42 & 1.47 & 0.71 & 0.89 \\
\hline I have perceived the cost of time spent traveling to the stadium as ... & 4.23 & 1.53 & 0.63 & 0.90 \\
\hline $\begin{array}{l}\text { In general, I have perceived the loss of time when attending Pamesa Valencia } \\
\text { matches as ... }\end{array}$ & 4.76 & 1.58 & 0.80 & 0.87 \\
\hline $\begin{array}{l}\text { I have perceived the time spent attending Pamesa Valencia matches as the time } \\
\text { that could have been spent on other things as... }\end{array}$ & 4.80 & 1.63 & 0.78 & 0.87 \\
\hline $\begin{array}{l}\text { I have perceived the effort I make in leaving other things (such as a family, } \\
\text { couple ... ) to attend the Pamesa Valencia matches as ... }\end{array}$ & 4.72 & 1.63 & 0.75 & 0.88 \\
\hline $\begin{array}{l}\text { In general, the time and effort dedicated to enjoying the experience of attending } \\
\text { the Pamesa Valencia matches are ... }\end{array}$ & 4.40 & 1.71 & 0.71 & 0.89 \\
\hline
\end{tabular}

Note: EFV—Efficiency value; SOV—Social value; ENV—Entertainment value; PMCV—Price and Monetary cost value; PRV—Perceived risk value; TEV—Time and effort Value. In parentheses is the item number in the original questionnaire. Acceptable composite reliability coefficient (CRC) $\geq 0.70$ Acceptable AVE $\geq 0.40$.

\subsection{Reliability Analysis}

The internal consistency was calculated using Cronbach's alpha to examine the reliability of the scale. However, since this index does not consider the influence on the reliability of the other construct, both the composite reliability coefficient (CRC) and the average extracted variance (AVE) were calculated [101]. Although the minimum CR value considered adequate is 0.70 [102] and values above 0.50 are recommended for AVE $[103,104]$, some articles have also considered values above 0.40 as adequate [105]. The adaptation of the Multidimensional Scale of Perceived Value (PVSE) by [40] obtained a total alpha value of 0.81 , while the different dimensions presented alpha values between 0.77 and 0.94 (EFV $\alpha=0.94$; SOV $\alpha=0.91$; ENV $\alpha=0.77$; PMCV $\alpha=0.89$; PRV $\alpha=0.91$; TEV $\alpha=0.90)$. In addition, all six dimensions presented acceptable values for the CRC (0.82-0.94) and TEV $(0.61-0.80)[101,105,106]$. These results are shown in Table 1.

\subsection{Validity Analysis}

Subsequently, the factorial validity, convergent and discriminant validity, construct validity, and scale criterion validity were analyzed. An exploratory factor analysis (EFA) and two confirmatory analyses were performed to study factorial validity.

First, sample adequacy was evaluated using the Kaiser-Meyer-Olkin test $(\mathrm{KMO}=0.85)$ and the Bartlett sphericity test $(p<0.01)$. Here, using the analyses of the mean components, an EFA was 
calculated with the Varimax rotation with a selection criterion of eigenvalues greater than 1 . The model obtained consists of six factors that explain $75.45 \%$ of the variance, which precisely replicates the authors' proposal.

To increase the robustness of the EFA result to ensure the factorial validity of the instrument independently of the sample, the model was tested twice: With a pilot sample, a random subsample of the total sample, and with each participant (final population). This procedure was possible because there were more than 200 individuals in each of the different samples [107]. In each analysis [108], the ML (maximum likelihood) estimation was used with the robust Satorra-Bentler correction, since it is the most robust estimation method with non-normal data.

Concerning the importance of $\chi^{2}(p<0.01)$, in no case can a proper setting be guaranteed. However, since this statistic is closely related to the size of the sample, other indicators were analyzed, such as the relationship between $\chi^{2}$ and its degrees of freedom (values below five considered acceptable) [109,110], as well as goodness-of-fit indices, such as the Normalized Adjustment Index (NFI), the Comparative Fit Index (CFI), and the Incremental F Index (IFI) (values above 0.90 indicate a good fit) [111] and the RMSEA, where values below 0.08 are indicators of a good fit, and optimal values are those below 0.05 [112]. The results obtained seem to justify the factorial validity of the instrument. Table 2 shows a summary of these indicators.

Table 2. Goodness-of-fit indexes for the Perceived Value Scale.

\begin{tabular}{cccccccccc}
\hline Model & $\chi^{2}(\mathbf{g l})$ & S-B $\chi^{2}(\mathbf{g l})$ & S-B $\chi^{2} /(\mathbf{g l})$ & NNFI & CFI & IFI & RMSEA & RMSEA CI & $\alpha$ Cronbach \\
\hline Sample $\mathrm{n}=277$ & $\begin{array}{c}727.52 \\
(284)\end{array}$ & $\begin{array}{c}534.17 \\
(284)\end{array}$ & 1.88 & 0.93 & 0.94 & 0.94 & 0.058 & $0.05-0.06$ & 0.82 \\
\hline $\begin{array}{c}\text { Final population } \\
\mathrm{n}=493\end{array}$ & $\begin{array}{c}981.22 \\
(284)\end{array}$ & $\begin{array}{c}711.68 \\
(284)\end{array}$ & 2.50 & 0.93 & 0.94 & 0.94 & 0.057 & $0.05-0.06$ & 0.81 \\
\hline
\end{tabular}

Note: $\chi^{2} / g 1 ;$ S-B $\chi^{2} /$ gl: adequate $\leq 5$; NNFI, Comparative Fit Index (CFI), Incremental F Index (IFI) $\geq 0.90$; RMSEA $\leq 0.80$; CI: Confidence interval.

In order to increase the empirical evidence on construct validity, the convergent and discriminant validity of the scale was calculated. Convergent validity appeared to be adequate, showing a strong significant correlation between the elements of the scale and the latent variables they were supposed to measure, with $t$ values above 3.291 in each case [106] and loads for each factor above 0.70 on average [104], which did not improve when new loads were included.

On the other hand, discriminant validity was evaluated using the mean extracted variance (AVE) test $[101,113]$. The square root of AVE was calculated to determine the existence of discriminant validity. These values must be higher than the correlation between the pairs of factors or dimensions considered $[101,106,113]$. The results, shown in Table 4, suggest acceptable discriminant validity.

After the analysis, and as suggested by the literature, the relationships of the construct with other constructs were examined to determine the criterion/nomological validity of this instrument [44]. First, the descriptive analyses of the variables under study were calculated (see Table 3). As can be observed in Table 3, the value dimension that presents the higher mean is the entertainment value $(M=5.49$; $\mathrm{DT}=0.98)$, followed by the perceived risk value $(\mathrm{M}=5.47 ; \mathrm{DT}=1.45)$. Regarding the value dimensions with lower means, the efficiency dimension stands out $(\mathrm{M}=3.37$; $\mathrm{DT}=1.48)$, followed by the price and monetary $\operatorname{cost}(\mathrm{M}=3.78$; $\mathrm{DT}=1.22)$.

After that, Pearson's correlation coefficients were then calculated for the perceived value, satisfaction, and future intention dimensions (see Table 4). In general, the questionnaire dimensions correlate significantly $(p<0.01)$, moderately or strongly, with the one-dimensional scale of perceived value, except in the TEV dimension $(p>0.05)$. Likewise, correlations are positive in all cases, except in the case of PMCV $(r=-0.17 ; p<0.01)$. The strongest association was found with the entertainment value $(r=0.61 ; p=0.01)$. Considering the rest of the constructs evaluated, the dimensions of the multidimensional perceived value scale correlate significantly $(p<0.01)$ with the future intentions and satisfaction scales, except the TEV with the satisfaction. 
Table 3. Descriptive statistics: Range, means, standard deviations, and alpha coefficients of the study variables.

\begin{tabular}{ccccc}
\hline Variables & Range & $\boldsymbol{M}$ & SD & $\boldsymbol{\alpha}$ \\
\hline EFV & $1-7$ & 3.37 & 1.48 & 0.65 \\
SOV & $1-7$ & 4.93 & 1.14 & 0.59 \\
ENV & $1-7$ & 5.49 & 0.98 & 0.63 \\
PMCV & $1-7$ & 3.78 & 1.22 & 0.65 \\
PRV & $1-7$ & 5.47 & 1.45 & 0.61 \\
TEV & $1-7$ & 4.55 & 1.31 & 0.63 \\
UGVALUE & $1-7$ & 5.15 & 1.09 & 0.91 \\
FI & $1-7$ & 6.19 & 0.88 & 0.88 \\
SAST & $1-7$ & 5.47 & 1.10 & 0.93
\end{tabular}

Note: EFV—Efficiency value; SOV_Social value; ENV—Entertainment value; PMCV—Price and monetary cost value; PRV-Perceived risk value; TEV-Time and effort value; UGVALUE-Unidimensional general value; FI-Future Intentions; SAST—Satisfaction.

In addition, a model was tested using SEM by means of the ML method with robust S-B correction, where the six dimensions of the perceived value scale were predictors of general satisfaction and future intentions. The adjustment indexes obtained for the model were: $\chi^{2} / \mathrm{gl}(1624.40 / 533=3.05)$; $\mathrm{SB}^{2}{ }^{22} / \mathrm{gl}=(1220.52 / 533=2.29) ; \mathrm{RMSEA}=0.05 ; \mathrm{NNFI}=0.92 ; \mathrm{CFI}=0.93 ; \mathrm{IFI}=0.93$. This suggests a proper model fit (Figure 1).

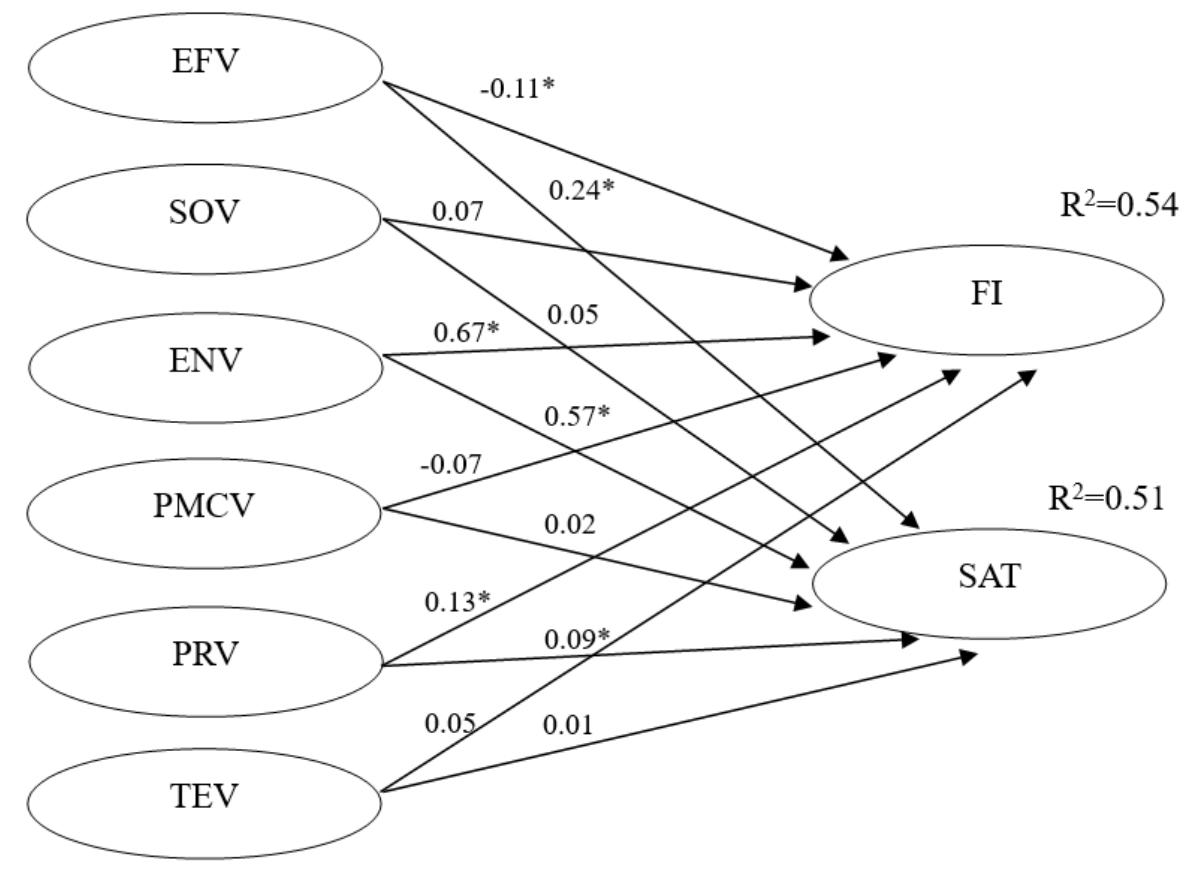

Figure 1. Predictor model of future intentions and general satisfaction using the dimensions of the perceived value scale as antecedents. Note: EFV—Efficiency value; SOV—Social value; ENV-Entertainment value; PMCV-Price and monetary cost value; PRV-Perceived risk value; TEV-Time and effort value; UGVALUE-Unidimensional general value; FI-Future intentions; SAT-Satisfaction. ${ }^{*} p<0.001 ; \chi^{2} / \mathrm{gl}(1624.40 / 533=3.05) ; \mathrm{SB}-\chi^{2} / \mathrm{gl}=(1220.52 / 533=2.29) ; \mathrm{RMSEA}=0.05$; $\mathrm{NNFI}=0.92 ; \mathrm{CFI}=0.93 ; \mathrm{IFI}=0.93$.

Based on the observed results, it seems that the dimensions of the perceived value scale predict $54 \%$ of the future intentions of the attendees to return from attending a sporting event, and $51 \%$ of their satisfaction with the sporting event. In the case of future intentions, the entertainment dimension ( $\beta=0.57)$ was the most important in predicting this variable, followed by the perceived risk value ( $\beta=0.13$ ), which exerted a positive influence on IF. However, the efficiency value exerted a significant 
but negative impact on IF ( $\beta=-0.11$ ). Hence, hypothesis one is accepted due to the capability of spectators' perceived value to predict sport consumers' future intentions.

On the other hand, in the case of satisfaction, the entertainment dimension $(\beta=0.67)$ was also the most reliable predictor, followed by the efficiency value $(\beta=0.24)$ and the perceived risk value $(\beta=0.09)$. All of these values exerted a statistically significant positive relationship with the SAT. Hence, hypothesis one is accepted due to the capability of spectators' perceived value to predict sport consumers' satisfaction.

\subsection{Correlation}

The next step in the validation of the scale was the analysis of Pearson's correlations between the dimensions of the instrument (Table 4 ) using the total sample or the final population. There were statistically significant correlations between each dimension $(p<0.01)$, except in the dimension of PRV with the EFV and SOV dimensions, and in the TEV dimension with the SOV and ENV dimensions. The correlations are moderate and positive, except for the PMCV and TEV dimensions, which are negative with some of them.

Table 4. Correlations between the dimensions of the perceived value scale and the unidimensional perceived value scale, future intentions, and general satisfaction.

\begin{tabular}{lccccccccc}
\hline & $\mathbf{1}$ & $\mathbf{2}$ & $\mathbf{3}$ & $\mathbf{4}$ & $\mathbf{5}$ & $\mathbf{6}$ & $\mathbf{7}$ & $\mathbf{8}$ & $\mathbf{9}$ \\
\hline 1.EFV & $(0.89)$ & & & & & & & & \\
2.SOV & $0.28^{* *}$ & $(0.80)$ & & & & & & \\
3.ENV & $0.29^{* *}$ & $0.40^{* *}$ & $(0.79)$ & & & & & \\
4.PMCV & $-0.27^{* *}$ & $-0.18^{* *}$ & $-0.17^{* *}$ & $(0.82)$ & & & & \\
5.PRV & 0.02 & 0.02 & $0.12^{* *}$ & $0.10^{*}$ & $(0.88)$ & & & \\
6.TEV & $-0.13^{* *}$ & -0.06 & 0.03 & $0.35^{* *}$ & $0.38^{* *}$ & $(0.78)$ & & & \\
7.UGVALUE & $0.40^{* *}$ & $0.38^{* *}$ & $0.61^{* *}$ & $-0.17^{* *}$ & $0.15^{* *}$ & 0.05 & - & & \\
8.FI & $0.13^{* *}$ & $0.31^{* *}$ & $0.55^{* *}$ & $-0.13^{* *}$ & $0.26^{* *}$ & $0.14^{* *}$ & $0.52^{* *}$ & - \\
9.SAT & $0.38^{* *}$ & $0.34^{* *}$ & $0.56^{* *}$ & $-0.18^{* *}$ & $0.17^{* *}$ & 0.04 & $0.62^{* *}$ & $0.53^{* *}$ & - \\
\hline
\end{tabular}

Note: EFV—Efficiency value; SOV—Social value; ENV—Entertainment value; PMCV—Price and monetary cost value; PRV-Perceived risk value; TEV-Time and effort value; UGVALUE-Unidimensional general value; FI-Future intentions; SAT—Satisfaction. ${ }^{*} p<0.05 ;{ }^{* *} p<0.01$; AVE square root in the diagonal.

\section{Discussion}

The importance of this work lies in the possibility of taking a further step in the evaluation of sports services, and particularly sporting events. The use of one-dimensional scales does not provide sufficient information for managers to make decisions to improve their actions or processes. In this case, the use of a multidimensional scale that can provide more information can be a significant step towards improving the satisfaction and future intentions of clients or sports spectators. Moreover, specifically in this scale of perceived value, both positive and negative dimensions are used, which is one of the most differentiating steps in terms of existing studies, which use only the quality variable as a multidimensional one.

The reliability of the six dimensions of the proposed value scale can generally be considered as good, with internal and external consistency being better suited for all values (benefits and costs). Furthermore, the values related to the benefits perceived by the spectators of sporting events correspond to the structure proposed by [66]. However, in this study, the value of spirituality is not considered. Regarding the dimensionality of the sacrifices, the structure also corresponded to the proposal of three main costs, such as the scale proposed by previous research [40]. It is also in line with some of the dimensions proposed by [44], such as the economic and social dimensions. Therefore, these results empirically corroborate the claim of certain authors that perceived value has both costs or sacrifices and benefits $[27,38,54,63,64]$. Hence, this multidimensional scale for measuring perceived value in 
sporting events goes a step further than those previously proposed [44] by using both negative (costs or sacrifices) and positive values (benefits).

Concerning the different dimensions of the perceived quality scale, there were statistically significant correlations between each dimension, except in the dimension of PRV with the EFV and SOV dimensions and in the TEV dimension with the SOV and ENV dimensions. Moreover, all the correlations were moderate and positive, except for the PMCV and TEV dimensions, which were negative. However, this is not strange, since they are two of the cost or negative dimensions of the perceived value scale. Hence, this corroborates that these two values are cost or negative aspects. Moreover, in the case of PRV, which is the third cost, the relationships with the other dimensions were positive, although no association was found with the EFV and SOV dimensions. Moreover, no association was found between the TEV dimension and the SOV and ENV dimensions. As in the study by [40], the correlations between dimensions found in this study are lower than those in other studies [44,54], so the typology of [66] allows a more complete and comprehensive view of the dimensionality of perceived value in the field of sports than other typologies of perceived value.

On the other hand, the highest correlation between the different dimensions of the perceived value was found between the dimensions of social value and entertainment. This finding is in line with the results found by [40]. In addition, this is in line with the data from [44], who found the strongest correlations between escapism and social value. Hence, escapism could be, in some ways, a similar concept of entertainment. This highlights the importance of social relations during sporting events. Therefore, this association should be considered when organizing sports events by trying to establish areas and moments that give rise to this type of social interaction. Hence, the present research indicates the perceived value is a complex variable, and a multidimensional conceptualization is required in a spectator sport context, as [44] previously highlighted.

Then, the validity of the scale was studied, leading to a model with the six perceived value factors or dimensions that predicted a high percentage of the variance of satisfaction and future intentions. Concretely, these value dimensions explain $54 \%$ of the variance of future intentions and $51 \%$ of the variance of the satisfaction of sports spectators. Hence, this multidimensional scale of perceived value shows its validity in predicting these two outcomes, as previous studies have proved, but with unidimensional scales [16-18]. Moreover, these findings highlight the importance of perceived value and the high predictive value of this variable $[16,36,37,63]$.

Regarding the most crucial value in predicting the satisfaction and future intentions of sporting event spectators, entertainment exerted the most considerable influence on these variables. This finding is in line with several studies that have found hedonic value to be the most important predictor of customer satisfaction [114-116]. Moreover, in the sporting event context, the hedonic value was a predictor of behavioral intentions [117]. The importance of entertainment to satisfaction and future intentions could be because sporting events are a hedonic service, and consumers expect that emotional gratification [118], so the outcome is not evaluated concerning its usefulness, but from an experiential perspective [119]. In addition, an interesting aspect is that the highest averages were in entertainment and social value, which were from students in spectator sports, concluding that they improve well-being [28] In addition, entertainment is one of the main reasons that spectators present for attending sporting events [120]. Moreover, motives of excitement and diversion have been found to have a significant effect on satisfaction and behavioral intention [121].

To sum up, it is necessary to highlight the originality of this study, since it is the first psychometric research on the PSV questionnaire adapted to the sports context, precisely that of sporting events, obtaining promising results. This study contributes to the suggestion of [47], who highlighted that further work is needed to operationalize other dimensions of perceived value that are difficult. Moreover, the multidimensional scale for perceived value in sport validated by [44] considers positive aspects of the perceived value. Hence, this study goes one step further by incorporating both positive and negative dimensions of the perceived value in the sports sector. Therefore, this scale can be considered a useful and practical tool with which to assess the perceived value in sporting events. 
In addition, this scale will help to collect specific information of high relevance for sports managers that can be used to improve the satisfaction and future intentions of their customers.

Finally, it is necessary to highlight that this research presents several limitations that give opportunities for future research. The main limitations of this research were the focus on one country and specific sporting events. Hence, the sample might not be representative of the whole population of sporting event consumers. Therefore, the stability and predictive ability of the scale require further empirical investigation, within the contexts of both other sports and other countries. Secondly, this survey can be adapted and used in other sports services. Hence, future studies should use it to evaluate other types of sports services. Thirdly, it is a cross-cultural study, and the stability of the questionnaires has not been analyzed. Thus, future longitudinal studies are necessary to prove the stability of this scale. Lastly, six dimensions were established in this multidimensional scale of perceived value. However, it is open to adding new dimensions if it is necessary, due to the fact that there is no agreement on the dimensions for measuring this variable. So, future studies should try to add new dimensions to improve the measurement of this complex variable in the sports sector.

\section{Conclusions}

The perceived value is an essential variable for the evaluation of sport consumer behavior to increase its satisfaction and future intentions. However, there is a lack of multidimensional scales in the sport management field that provide enough specific information to sport managers to be able to know the particular elements of the service that are presented as most relevant in the final result. Hence, with the development of this multidimensional scale of perceived value in the sporting event context, more specific information regarding the perceived value of sport consumers can be collected. Moreover, this scale considers not only the benefits of positive aspects, but also costs or negative elements, providing very enriching information on sport consumers' perceived value.

On the one hand, in relation to the positive values, the entertainment value was found to be the main predictor of both satisfaction and future intentions. Hence, sporting event managers must develop strategies to improve the perception of this value. For instance, they can organize a fun zone for the sporting event. In addition, they can prepare some entertainment activities to be performed during the break of the match. In addition, to close the sporting event, some kind of draw or festival could be a good strategy. Regarding the social value, strategies should be focused on the enhancement of the relationships between sport spectators. Hence, the strategies presented to improve the entertainment value can also be performed to increase the perception of this value. Finally, in relation to the efficiency value, the place or location where the event will be held is essential. Holding the sporting event in a facility where there are other leisure services, such as bars or shops, around is important in increasing the perception of this value.

On the other hand, concerning the costs, some strategies can also be carried out to reduce them. Firstly, concerning the price and monetary cost value, some bonuses or special offers for families can be created. In addition, agreements could be made with public transportation to reduce the price of commuting to attend the events. In addition, arrangements could be made with hotels to make special offers for those attending the sporting event. Secondly, regarding the perceived risk value, a sound security system for events could be hired, both public (police, civil protection ... ) and private. In addition, having a good health care network with ambulances and medical professionals in case something happens during the event can be another strategy. Finally, concerning the time and effort value, to hold the event in an easily accessible location with an excellent public transport network is essential. To schedule the sports event at a good time, where there is not much traffic, and where that does not interfere with daily routines is also important.

Therefore, this tool can be handy for sports managers to identify which specific aspects need to be improved so that their clients increase their perceived value. Sports managers should use this scale to determine what marketing strategies are required to increase the perceived value of sports spectators 
to guarantee the sustainability of sporting events. In this way, it will be easier for spectators of sporting events to be satisfied and have intentions of attending sporting events again.

Author Contributions: Conceptualization, J.C.H. and M.H.G.-S.; methodology, V.P.-G.; software, V.P.-G.; validation, V.P.-G., and J.C.H.; formal analysis, V.P.-G.; investigation, J.C.H.; data curation, J.C.H.; writing —original draft preparation, M.H.G.-S.; writing-review and editing, M.H.G.-S. and J.C.H.; supervision, J.C.H. All authors have read and agreed to the published version of the manuscript.

Funding: This research received no external funding.

Conflicts of Interest: The authors declare no conflict of interest.

\section{References}

1. Dos Santos, M.A.; Moreno, F.C.; Rios, F.M.; Valantine, I.; Emeljanovas, A. Destination image of a city hosting sport event: Effect on sponsorship. Transform. Bus. Econ. 2014, 13, 343-360.

2. Añó, V. Organización de Eventos y Competiciones Deportivas; Universitat de València: València, Spain, 2011.

3. Heere, B.; Wear, H.; Jones, A.; Breitbarth, T.; Xing, X.; Salcines, J.L.P.; Yoshida, M.; Derom, I. Inducing destination images among international audiences: The differing effects of promoting sport events on the destination image of a city around the world. J. Sport Manag. 2019, 33, 506-517. [CrossRef]

4. Bain-Selbo, E. Sport and social change: The prophetic dimension. In The Prophetic Dimension of Sport; Springer: New York, NY, USA, 2019; pp. 7-14.

5. Ekholm, D. Sport as a means of governing social integration: Discourses on bridging and bonding social relations. Sociol. Sport J. 2019, 36, 152-161. [CrossRef]

6. Omorou, Y.A.; Erpelding, M.-L.; Escalon, H.; Vuillemin, A. Contribution of taking part in sport to the association between physical activity and quality of life. Qual. Life Res. 2013, 22, 2021-2029. [CrossRef]

7. Martin, D.S.; Howell, R.; Newman, C.; Martin, K. Validation of Eventserv-Short. Manag. Serv. Qual. Int. J. 2012, 22, 386-398. [CrossRef]

8. Theodorakis, N.D.; Kaplanidou, K.; Alexandris, K.; Papadimitriou, D. From sport event quality to quality of life: The role of satisfaction and purchase happiness. J. Conv. Event Tour. 2019, 20, 241-260. [CrossRef]

9. Ma, S.C.; Kaplanidou, K. Service quality, perceived value and behavioral intentions among highly and lowly identified baseball consumers across nations. Int. J. Sports Mark. Spons. 2019, 21, 46-69. [CrossRef]

10. Scarpi, D.; Pizzi, G.; Raggiotto, F.; Mason, M. A qualitative comparative analysis (QCA) of satisfaction toward extreme sporting Events. Australas. Mark. J. 2018, 26, 358-368. [CrossRef]

11. Çevik, H.; Şimşek, K.Y. The effect of event experience quality on the satisfaction and behavioral intentions of motocross World Championship spectators. Int. J. Sports Mark. Spons. 2020, 21, 389-408. [CrossRef]

12. Crespo, J.; Mundina, J.; Calabuig, F.; Aranda, R. Perceived quality of basketball spectators. A measurement scale validation. Rev. Psicol. Deporte 2013, 22, 195-198.

13. González-García, R.J.; Parra, D.; Ferran, C.; Añó, V. Resident's perceptions regarding Mundobasket 2014 in Gran Canaria (Spain) and support to sport events celebration. Rev. Iberoam. Psicol. Ejerc. Deporte 2016, 11, 279-298.

14. Parra-Camacho, D.; Añó, V.; Ayora, D.; González-García, R.J. Applying importance-performance analysis to residents' perceptions of large sporting events. Sport Soc. 2020, 23, 249-263. [CrossRef]

15. Sánchez-Sáez, J.A.; Segado, F.S.; Vidal, A. Los eventos deportivos socialmente responsables como motor del desarrollo local. J. Sports Econ. Manag. 2018, 8, 172-1786.

16. Calabuig, F.; Prado-Gasco, V.; Crespo, J.; Núñez-Pomar, J.; Añó, V. Spectator emotions: Effects on quality, satisfaction, value, and future intentions. J. Bus. Res. 2015, 68, 1445-1449. [CrossRef]

17. Dos-Santos, M.A.; Calabuig, F.; Montoro Ríos, F.; Alguacil, M. Online sport event consumers: Attitude, E-quality and E-satisfaction. J. Theor. Appl. Electron. Commer. Res. 2017, 12, 54-70. [CrossRef]

18. Hyun, M.; Jordan, J.S. Athletic goal achievement: A critical antecedent of event satisfaction, re-participation intention, and future exercise intention in participant sport events. Sport Manag. Rev. 2019, 23, 256-270. [CrossRef]

19. Prayag, G.; Grivel, E. Antecedents of Sport Event Satisfaction and Behavioral Intentions: The Role of Sport Identification, Motivation, and Place Dependence. Event Manag. 2018, 22, 423-439. [CrossRef] 
20. Kim, S.-K.; Park, J.-A.; Kim, W. The mediating effect of destination image on the relationship between spectator satisfaction and behavioral intentions at an international sporting event. Asia Pac. J. Tour. Res. 2016, 21, 273-292. [CrossRef]

21. Lee, J.-H.; Kim, H.-D.; Ko, Y.J.; Sagas, M. The influence of service quality on satisfaction and intention: A gender segmentation strategy. Sport Manag. Rev. 2011, 14, 54-63. [CrossRef]

22. Murray, D.; Howat, G. The relationships among service quality, value, satisfaction, and future intentions of customers at an Australian sports and leisure centre. Sport Manag. Rev. 2002, 5, 25-43. [CrossRef]

23. Shonk, D.J.; Chelladurai, P. Service quality, satisfaction, and intent to return in event sport tourism. J. Sport Manag. 2008, 22, 587-602. [CrossRef]

24. Xiao, Y.; Ren, X.; Zhang, P.; Ketlhoafetse, A. The effect of service quality on foreign participants' satisfaction and behavioral intention with the 2016 Shanghai International Marathon. Int. J. Sports Mark. Spons. 2019, 21, 91-105. [CrossRef]

25. García-Fernández, J.; Gálvez-Ruíz, P.; Fernández-Gavira, J.; Vélez-Colón, L.; Pitts, B.; Bernal-García, A. The effects of service convenience and perceived quality on perceived value, satisfaction and loyalty in low-cost fitness centers. Sport Manag. Rev. 2018, 21, 250-262. [CrossRef]

26. Jin, N.; Lee, H.; Lee, S. Event quality, perceived value, destination image, and behavioral intention of sports events: The case of the IAAF World Championship, Daegu, 2011. Asia Pac. J. Tour. Res. 2013, 18, 849-864. [CrossRef]

27. Moon, K.-S.; Ko, Y.J.; Connaughton, D.P.; Lee, J.-H. A mediating role of destination image in the relationship between event quality, perceived value, and behavioral intention. J. Sport Tour. 2013, 18, 49-66. [CrossRef]

28. Kim, J.W.; Magnusen, M.; Lee, H.-W. Existence of mixed emotions during consumption of a sporting event: A real-time measure approach. J. Sport Manag. 2017, 31, 360-373. [CrossRef]

29. Trail, G.T.; Anderson, D.F.; Lee, D. A longitudinal study of team-fan role identity on self-reported attendance behavior and future intentions. J. Amat. Sport 2017, 3, 27-49. [CrossRef]

30. Lee, H.-W.; Cho, H.; Newell, E.M.; Kwon, W. How multiple identities shape behavioral intention: Place and team identification on spectator attendance. Int. J. Sports Mark. Spons. 2020. [CrossRef]

31. Funk, D.C.; Filo, K.; Beaton, A.A.; Pritchard, M. Measuring the motives of sport event attendance: Bridging the academic-practitioner divide to understanding behavior. Sport Mark. Q. 2009, 18, 126.

32. Funk, D.C.; Mahony, D.F.; Nakazawa, M.; Hirakawa, S. Development of the Sport Interest Inventory (SII): Implications for measuring unique consumer motives at team sporting Events. Int. J. Sports Mark. Spons. 2001, 3, 291-317. [CrossRef]

33. Nuviala, A.; Grao-Cruces, A.; Pérez-Turpin, J.A.; Nuviala, R. Perceived service quality, perceived value and satisfaction in groups of users of sports organizations in Spain. Kinesiology 2012, 44, 94-103.

34. Cronin, J.J., Jr.; Taylor, S.A. Measuring service quality: A reexamination and extension. J. Mark. 1992, 56, 55-68. [CrossRef]

35. Pérez-Campos, C.; Alonso-Dos-Santos, M. La importancia de los atributos del servicio y el valor percibido en la predicción de la satisfacción de los espectadores de balonmano. J. Sports Econ. Manag. 2013, 3, 33-46.

36. Calabuig, F.; Crespo, J.; Núñez-Pomar, J.; Valantinè, I.; Staškevičiūtè-Butienè, I. Role of perceived value and emotions in the satisfaction and future intentions of spectators in sporting events. Inžineriné Ekon. 2016, 27, 221-229.

37. Tam, J.L. Customer satisfaction, service quality and perceived value: An integrative model. J. Mark. Manag. 2004, 20, 897-917. [CrossRef]

38. Gallarza, M. Gil-Saura, I. Value dimensions, perceived value, satisfaction and loyalty: An investigation of university students' travel behaviour. Tour. Manag. 2006, 27, 437-452. [CrossRef]

39. Gil-Saura, I.; Gallarza, M. Investigating perceived value from a marketing viewpoint. Innovar. Rev. Ciencias Adm. Soc. 2008, 18, 9-17.

40. Gallarza, M.; Gil-Saura, I. Desarrollo de una escala multidimensional para medir el valor percibido de una experiencia de servicio. Rev. Española Investig. Mark. 2006, 10, 25-59.

41. Hightower, R., Jr.; Brady, M.K.; Baker, T.L. Investigating the role of the physical environment in hedonic service consumption: An exploratory study of sporting events. J. Bus. Res. 2002, 55, 697-707. [CrossRef]

42. Calabuig, F.; Burillo, P.; Crespo, J.; Mundina, J.J.; Gallardo, L. Satisfacción, calidad y valor percibido en espectadores de atletismo. Int. J. Med. Sci. Phys. Act. Sport 2010, 10, 577-593. 
43. Cronin, J.J.; Brady, M.K.; Hult, G.T.M. Assessing the effects of quality, value, and customer satisfaction on consumer behavioral intentions in service environments. J. Retail. 2000, 76, 193-218. [CrossRef]

44. Kunkel, T.; Doyle, J.P.; Berlin, A. Consumers' perceived value of sport team games-A multidimensional approach. J. Sport Manag. 2017, 31, 80-95. [CrossRef]

45. Petrick, J.F. Development of a multidimensional scale for measuring the perceived value of a service. J. Leis. Res. 2002, 34, 119-134. [CrossRef]

46. Westerbeek, H.M.; Shilbury, D. A conceptual model for sport services marketing research: Integrating quality, value and satisfaction. Int. J. Sports Mark. Spons. 2003, 5, 11-31. [CrossRef]

47. Sánchez-Fernández, R.; Iniesta-Bonillo, M.Á. Efficiency and quality as economic dimensions of perceived value: Conceptualization, measurement, and effect on satisfaction. J. Retail. Consum. Serv. 2009, 16, 425-433. [CrossRef]

48. Byon, K.K.; Zhang, J.J.; Baker, T.A. Impact of core and peripheral service quality on consumption behavior of professional team sport spectators as mediated by perceived value. Eur. Sport Manag. Q. 2013, 13, 232-263. [CrossRef]

49. Kwon, H.H.; Trail, G.; James, J.D. The mediating role of perceived value: Team identification and purchase intention of team-licensed apparel. J. Sport Manag. 2007, 21, 540-554. [CrossRef]

50. Zeithaml, V.A. Consumer perceptions of price, quality, and value: A means-end model and synthesis of evidence. J. Mark. 1988, 52, 2-22. [CrossRef]

51. Woodruff, R.B.; Gardial, S. Know Your Customer: New Approaches to Understanding Customer Value and Satisfaction; Wiley: Weinheim, Germany, 1996.

52. Woodruff, R.B. Customer value: The next source for competitive advantage. J. Acad. Mark. Sci. 1997, 25, 139-153. [CrossRef]

53. Gale, B.; Gale, B.T.; Wood, R.C. Managing Customer Value: Creating Quality and Service that Customers Can See; Simon and Schuster: New York, NY, USA, 1994.

54. Sweeney, J.C.; Soutar, G.N. Consumer perceived value: The development of a multiple item scale. J. Retail. 2001, 77, 203-220. [CrossRef]

55. Theakou, E.; Kriemadis, A.; Leivadi, S. A management-oriented approach to understanding customer value: The case of a private fitness club in Greece. In Proceedings of the Work Presented in the $16^{\circ}$ European Association of Sport Management Conference, Prague, Czech Republic, 10-13 September 2008.

56. Grönroos, C. Keynote paper from marketing mix to relationship marketing-towards a paradigm shift in marketing. Manag. Decis. 1997, 35, 332-339. [CrossRef]

57. Sabiote Ortiz, C.M. Valor Percibido Global del Proceso de Decisión de Compra Online de un Producto Turístico. Efecto Moderador de la Cultura. Ph.D. Thesis, Universidad de Granada, Granada, Spain, 2010.

58. Oliver, R.L. Whence consumer loyalty? J. Mark. 1999, 63, 33-44. [CrossRef]

59. Rust, R.T.; Oliver, R.W. The death of advertising. J. Advert. 1994, 23, 71-77. [CrossRef]

60. Baena-Arroyo, M.J.; García-Fernández, J.; Bernal-García, A.; Lara-Bocanegra, A.; Gálvez-Ruíz, P. Perceived value and customer satisfaction in virtual fitness and trainer-guided group activities in fitness centres. Rev. Psicol. Deporte 2016, 25, 219-227.

61. Martín-Ruiz, D.; Barroso-Castro, C.; Rosa-Díaz, I.M. Creating customer value through service experiences: An empirical study in the hotel industry. Tour. Hosp. Manag. 2012, 18, 37-53.

62. Wang, Y.; Lo, H.P.; Chi, R.; Yang, Y. An integrated framework for customer value and customer-relationshipmanagement performance: A customer-based perspective from China. Manag. Serv. Qual. 2004, 14, 169-182. [CrossRef]

63. McDougall, G.H.; Levesque, T. Customer satisfaction with services: Putting perceived value into the equation. J. Serv. Mark. 2000, 14, 392-410. [CrossRef]

64. Yu, H.S.; Zhang, J.J.; Kim, D.H.; Chen, K.K.; Henderson, C.; Min, S.D.; Huang, H. Service quality, perceived value, customer satisfaction, and behavioral intention among fitness center members aged 60 years and over. Soc. Behav. Personal. Int. J. 2014, 42, 757-767. [CrossRef]

65. Sheth, J.N.; Newman, B.I.; Gross, B.L. Consumption Values and Market Choices: Theory and Applications; South-Western Pub.: Cinicinnati, OH, USA, 1991.

66. Holbrook, M.B. Consumer Value: A Framework for Analysis and Research; Routeledge: London, UK, 1999.

67. Gallarza, M.G.; Francés, D.S.; Moreno, F.A.; Gil-Saura, I. Value's Dimensionality in the Volunteer Experience in a Tourism Mega-Event. Eur. J. Manag. Bus. Econ. 2010, 19, 149-170. 
68. Pons, F.; Mourali, M.; Nyeck, S. Consumer orientation toward sporting events: Scale development and validation. J. Serv. Res. 2006, 8, 276-287. [CrossRef]

69. Mathwick, C.; Malhotra, N.K.; Rigdon, E. The effect of dynamic retail experiences on experiential perceptions of value: An Internet and catalog comparison. J. Retail. 2002, 78, 51-60. [CrossRef]

70. Monga, M. Measuring motivation to volunteer for special events. Event Manag. 2006, 10, 47-61. [CrossRef]

71. Dowling, G.R.; Staelin, R. A model of perceived risk and intended risk-handling activity. J. Consum. Res. 1994, 21, 119-134. [CrossRef]

72. Ingene, C.A.; Hughes, M.A. Risk management by consumers. Res. Consum. Behav. 1985, 1, $103-158$.

73. Littler, D.; Melanthiou, D. Consumer perceptions of risk and uncertainty and the implications for behaviour towards innovative retail services: The case of internet banking. J. Retail. Consum. Serv. 2006, 13, 431-443. [CrossRef]

74. Anderson, E.W.; Shugan, S.M. Repositioning for changing preferences: The case of beef versus poultry. J. Consum. Res. 1991, 18, 219-232. [CrossRef]

75. Heinonen, K. Reconceptualizing customer perceived value: The value of time and place. Manag. Serv. Qual. Int. J. 2004, 14, 205-215. [CrossRef]

76. Leclerc, F.; Schmitt, B. Aesthetic Value: Beauty in Art and Fashion. Consumer Value: A Framework for Analysis and Research. Routledge Interpretative Marketing Series; Routledge: London, UK, 1999.

77. Choi, K.-S.; Cho, W.-H.; Lee, S.; Lee, H.; Kim, C. The relationships among quality, value, satisfaction and behavioral intention in health care provider choice: A South Korean study. J. Bus. Res. 2004, 57, 913-921. [CrossRef]

78. Ryu, K.; Lee, H.-R.; Kim, W.G. The influence of the quality of the physical environment, food, and service on restaurant image, customer perceived value, customer satisfaction, and behavioral intentions. Int. J. Contemp. Hosp. Manag. 2012, 24, 200-223. [CrossRef]

79. Sanchez, J.; Callarisa, L.; Rodriguez, R.M.; Moliner, M.A. Perceived value of the purchase of a tourism product. Tour. Manag. 2006, 27, 394-409. [CrossRef]

80. Dorai, S.; Varshney, S. A multistage behavioural and temporal analysis of CPV in RM. J. Bus. Ind. Mark. 2012, 27, 403-411. [CrossRef]

81. Yang, Z.; Peterson, R.T. Customer perceived value, satisfaction, and loyalty: The role of switching costs. Psychol. Mark. 2004, 21, 799-822. [CrossRef]

82. Caruana, A.; Fenech, N. The effect of perceived value and overall satisfaction on loyalty: A study among dental patients. J. Med. Mark. 2005, 5, 245-255. [CrossRef]

83. Chen, S.-C.; Quester, P.G. Modeling store loyalty: Perceived value in market orientation practice. J. Serv. Mark. 2006, 20, 188-298. [CrossRef]

84. Liao, N.N.; Wu, T.C. The pivotal role of trust in customer loyalty: Empirical research on the system integration market in Taiwan. Bus. Rev. Camb. 2009, 12, 277-384.

85. Moliner, M.A.; Sánchez, J.; Rodríguez, R.M.; Callarisa, L. Relationship quality with a travel agency: The influence of the post-purchase perceived value of a tourism package. Tour. Hosp. Res. 2007, 7, 194-211. [CrossRef]

86. Allameh, S.M.; Pool, J.K.; Jaberi, A.; Salehzadeh, R.; Asadi, H. Factors influencing sport tourists' revisit intentions. Asia Pac. J. Mark. Logist. 2015, 27, 191-207. [CrossRef]

87. Clemes, M.D.; Brush, G.J.; Collins, M.J. Analysing the professional sport experience: A hierarchical approach. Sport Manag. Rev. 2011, 14, 370-388. [CrossRef]

88. Howat, G.; Assaker, G. The hierarchical effects of perceived quality on perceived value, satisfaction, and loyalty: Empirical results from public, outdoor aquatic centres in Australia. Sport Manag. Rev. 2013, 16, 268-284. [CrossRef]

89. Theodorakis, N.D.; Howat, G.; Ko, Y.J.; Avourdiadou, S. A comparison of service evaluation models in the context of sport and fitness centres in Greece. Manag. Leis. 2014, 19, 18-35. [CrossRef]

90. Chen, C.-F.; Chen, F.-S. Experience quality, perceived value, satisfaction and behavioral intentions for heritage tourists. Tour. Manag. 2010, 31, 29-35. [CrossRef]

91. Trail, G.T.; Anderson, D.F.; Fink, J.S. Consumer satisfaction and identity theory: A model of sport spectator conative loyalty. Sport Mark. Q. 2005, 14, 98-111.

92. Dodds, W.B.; Monroe, K.B.; Grewal, D. Effects of price, brand, and store information on buyers' product evaluations. J. Mark. Res. 1991, 28, 307-319. 
93. Jayanti, R.K.; Ghosh, A.K. Service value determination: An integrative perspective. J. Hosp. Leis. Mark. 1996, 3, 5-25. [CrossRef]

94. Quintal, V.A.; Polczynski, A. Factors influencing tourists' revisit intentions. Asia Pac. J. Mark. Logist. 2010, 22, 554-578. [CrossRef]

95. Choi, C.; Greenwell, T.C.; Lee, K. Effects of service quality, perceived value, and consumer satisfaction on behavioral intentions in virtual golf. J. Phys. Educ. Sport 2018, 18, 1459-1468.

96. Ekinci, Y.; Prokopaki, P.; Cobanoglu, C. Service quality in Cretan accommodations: Marketing strategies for the UK holiday market. Int. J. Hosp. Manag. 2003, 22, 47-66. [CrossRef]

97. Olever, R.L. Satisfaction: A Behavioral Perspective on the Customer; Irwin McGraw Hill: New York, NY, USA, 1997.

98. Barajas, A.; Calabuig, F.; Crespo, J.C.; Prado-Gascó, V.J.; Núñez-Pomar, J.M. Using a brief questionnaire to assess the overall perceptions of basketball spectators. Sport Bus. Manag. Int. J. 2014, 4, 212-222.

99. Calabuig, F.; Prado-Gascó, V.; Crespo, J.C.; Núñez-Pomar, J.; Añó, V. Predicting future intentions of basketball spectators using SEM and fsQCA. J. Bus. Res. 2016, 69, 1396-1400. [CrossRef]

100. Zeithaml, V.A.; Berry, L.L.; Parasuraman, A. The behavioral consequences of service quality. J. Mark. 1996, 60, 31-46. [CrossRef]

101. Fornell, C.; Larcker, D.F. Structural Equation Models with Unobservable Variables and Measurement Error: Algebra and Statistics; SAGE Publications: Los Angeles, CA, USA, 1981.

102. Nunnally, J.C. Psychometric Theory, 2nd ed.; Mcgraw Hill Book Company: New York, NY, USA, 1978.

103. Bagozzi, R.P.; Yi, Y. On the evaluation of structural equation models. J. Acad. Mark. Sci. 1988, 16, 74-94. [CrossRef]

104. Hair, J.F.; Black, W.C.; Babin, B.J.; Anderson, R.E.; Tatham, R.L. Multivariate Data Analysis; Pearson Prentice Hall: Upper Saddle River, NJ, USA, 2006; Volume 6.

105. Aldás, J. Problemas metodológicos de la evaluación de los modelos de exposición: Especial referencia al caso español. In Temas Planif. Medios; Bigné, J., Ed.; Esic: Madrid, Spain, 2000; pp. 89-114.

106. Vila, N.; Küster, I.; Aldás, J. Development and Validation of Marketing Scales; Work Books; Facultat d'Economia, Universitat de Valencia: Valencia, Spain, 2000; Volume 104.

107. Bentler, P.M. On tests and indices for evaluating structural models. Personal. Individ. Differ. 2007, 42, 825-829. [CrossRef]

108. Bentler, P.M. EQS Structural Equations Program Manual; Multivariate Software: Encino, CA, USA, 1995; Volume 6.

109. Byrne, B.M.; Shavelson, R.J.; Muthén, B. Testing for the equivalence of factor covariance and mean structures: The issue of partial measurement invariance. Psychol. Bull. 1989, 105, 456-466. [CrossRef]

110. Carmines, E.G.; McIver, J.P.; Bohrnstedt, G.W.; Borgatta, E.F. Social measurement: Current issues. Anal. Models Unobserved Var. Anal. Covariance Struct. 1981, 80, 65-115.

111. MacCallum, R.C.; Austin, J.T. Applications of structural equation modeling in psychological research. Annu. Rev. Psychol. 2000, 51, 201-226. [CrossRef]

112. Browne, M.W.; Cudeck, R.; Bollen, K.A.; Long, J.S. Testing Sructural Equation Models; Sage: London, UK, 1993.

113. Netemeyer, R.G.; Johnston, M.W.; Burton, S. Analysis of role conflict and role ambiguity in a structural equations framework. J. Appl. Psychol. 1990, 75, 148-157. [CrossRef]

114. El-Adly, M.I. Modelling the relationship between hotel perceived value, customer satisfaction, and customer loyalty. J. Retail. Consum. Serv. 2019, 50, 322-332. [CrossRef]

115. Carpenter, J.M. Consumer shopping value, satisfaction and loyalty in discount retailing. J. Retail. Consum. Serv. 2008, 15, 358-363. [CrossRef]

116. Hanzaee, K.H.; Rezaeyeh, S.P. Investigation of the effects of hedonic value and utilitarian value on customer satisfaction and behavioural intentions. Afr. J. Bus. Manag. 2013, 7, 818-825.

117. Yoshida, M.; James, J.D.; Cronin, J.J. Value creation: Assessing the relationships between quality, consumption value and behavioural intentions at sporting events. Int. J. Sports Mark. Spons. 2013, 14, 126-148. [CrossRef]

118. Kempf, D.S. Attitude formation from product trial: Distinct roles of cognition and affect for hedonic and functional products. Psychol. Mark. 1999, 16, 35-50. [CrossRef]

119. Babin, B.J.; Darden, W.R.; Griffin, M. Work and/or fun: Measuring hedonic and utilitarian shopping value. J. Consum. Res. 1994, 20, 644-656. [CrossRef] 
120. Consumer, C.S. Motivations across multiple sports. Sport Mark. Q. 2004, 13, 17-25.

121. Duan, Y.; Liu, B.; He, Y. Study on relationships among sports spectator motivations, satisfaction, and behavioral intention. Int. J. Sports Mark. Spons. 2019, 1464-1668. [CrossRef] 